\title{
Seasonality of eelgrass biomass across gradients in temperature and latitude
}

\author{
Kevin Kuhlmann Clausen ${ }^{1,2, *}$, Dorte Krause-Jensen ${ }^{2,3}{ }^{\text {, Birgit Olesen }}{ }^{4}$, Nuria Marbà ${ }^{5}$ \\ ${ }^{1}$ Department of Bioscience, Aarhus University, Grenåvej 14, 8410 Rønde, Denmark \\ ${ }^{2}$ Arctic Research Centre, Aarhus University, C.F. Møllers Allé 8, 8000 Aarhus C, Denmark \\ ${ }^{3}$ Department of Bioscience, Aarhus University, Vejlsøvej 25, 8600 Silkeborg, Denmark \\ ${ }^{4}$ Department of Bioscience, Aarhus University, Ole Worms Allé 1, Building 1135, 8000 Aarhus C, Denmark \\ ${ }^{5}$ Department of Global Change Research, IMEDEA (CSIC-UIB), Institut Mediterrani d'Estudis Avançats, Miquel Marquès 21,
} 07190 Esporles, Illes Balears, Spain

\begin{abstract}
Eelgrass Zostera marina L. meadows are major structural and trophic components of coastal ecosystems. The role of eelgrass in ecosystem functioning depends on biomass and production of the meadows, which can fluctuate greatly during an annual cycle and be major temporal drivers of changes in the coastal zone. We analysed magnitude and seasonality of eelgrass aboveground biomass, shoot density and production across temperature and latitude gradients over the majority of the species' distributional range, and investigated to what extent temperature and/or light drive differences in these values. Eelgrass phenology (timing of peak biomass, start and end of the growing season) showed strong effects of temperature and latitude, indicating that seasonality was considerably advanced in warm areas at low latitudes compared to cold areas at high latitudes. Magnitude of peak aboveground biomass, length of the growing season, mean annual shoot density and aboveground production did not change significantly with either temperature or latitude, indicating that these parameters were controlled mainly by other factors. Annual variation in aboveground biomass and shoot density was significantly smaller in areas with low summer temperature, indicating that while warm-water populations may show substantial temporal variation in biomass, cold-water meadows are less dynamic. These findings were supported by cold-water populations having a larger mean annual biomass and a greater investment in belowground parts. In all significant regressions, temperature was a better predictor of population dynamics than latitude. This indicates that eelgrass phenology might advance considerably in response to global warming, and suggests that the distributional range of this species might be moving northwards. Given the key role of eelgrass in coastal ecosystems, these climateinduced changes might entail substantial impacts on waterbirds, fish, invertebrates and other organisms exploiting these meadows.
\end{abstract}

KEY WORDS: Zostera marina $\cdot$ Climate change $\cdot$ Phenology $\cdot$ Waterbirds $\cdot$ Ecosystem functioning Resale or republication not permitted without written consent of the publisher

\section{INTRODUCTION}

Eelgrass meadows play key structural and trophic roles in coastal ecosystems. The surfaces of leaves and underground stems and roots as well as the spaces between them serve as habitat, shelter and nursing grounds for a wide spectrum of organisms, e.g. bacteria, algae, invertebrates, fish and other vertebrates (Franco et al. 2006, Fonseca et al. 2011). While few species graze directly on eelgrass, leaving much of the biomass for the detrivore food web (Cebrián et al. 1997), eelgrass serves as a key food source to many migrating and overwintering waterbirds (Nienhuis \& Groenendijk 1986, Clausen et al. 
2012). In several ways the meadows thus stimulate biodiversity and food web complexity. Moreover, eelgrass meadows dampen wave energy, trap particles, stabilize the sediments and contribute to carbon sequestration and nutrient cycling (Widdows et al. 2008, van Katwijk et al. 2010).

The structural diversity of eelgrass habitats and the associated biodiversity depend on the standing eelgrass biomass as well as on the continuous production of new leaves, rendering new surfaces available for colonization while old leaves decay. Similarly, the trophic role depends on meadow productivity as well as on the stimulating effect of meadow structure on food web complexity. The magnitude and dynamics of biomass and production are thus useful indicators of the potential roles of seagrass meadows (Duarte 1989, Sfrisco \& Ghetti 1998). In addition, the ratio of biomass to production reflects the turnover of the meadows. Annual biomass variability, timing of the growth season and peak biomass reflect the changes in habitat structure that seagrass-associated organisms are subjected to over an annual cycle. Earlier studies indicate that most of this variability reflects a predictable seasonal response rather than a random response (Duarte 1989).

Variation in eelgrass biomass and productivity over an annual cycle reflects seasonal changes in growth conditions such as temperature and light, and is therefore likely to change across the broad latitudinal range of the species. In Europe, this extends from sub-tropical conditions in southern Iberia at $36^{\circ} \mathrm{N}$ to Arctic conditions in northern Norway at $69^{\circ} \mathrm{N}$ (Green $\&$ Short 2003). A pioneering study indicated that seagrass biomass variability is generally constrained by latitude, with meadows at lower latitudes sustaining a more constant biomass and a tendency of greater daily production to biomass ratios compared to meadows further north (Duarte 1989). Whether this is also the case for eelgrass is yet to be explored. Recent studies indicate that eelgrass in the north exhibits lower annual leaf formation but similar maximum aboveground biomass compared to eelgrass further south (authors' unpubl. data). This suggests that northern populations in stable environments are able to maintain a large overwintering biomass, allowing high maximum aboveground biomass levels during the short growing season (Olesen \& Sand-Jensen 1994a). Correspondingly, we hypothesize that northern eelgrass populations do not conform to the pattern of increased seasonal variability northwards, identified for seagrasses in general (Duarte 1989). It is even probable that southern eelgrass populations exhibit more seasonal variation than northern ones, as high summer temperature has been reported to render some southern populations annual (Phillips et al. 1983). In addition, the maximum biomass achieved during summer is expected to be largely unaffected by latitude or temperature, because self-shading within the stands sets an upper limit for biomass development (Olesen \& Sand-Jensen 1994a).

Seagrass aboveground biomass fluctuations result from changes in shoot size and changes in shoot density (Olesen \& Sand-Jensen 1994a), with the cost of building new shoots being much more expensive in terms of nutrients and carbon than just producing leaves (Duarte 1991). Seasonality of biomass in small seagrass species (e.g. Cymodocea nodosa) can be largely explained by seasonal changes in shoot density, whereas in large species (e.g. Posidonia spp.), changes in leaf size are more important (Cebrián et al. 1997). If indeed eelgrass populations do not conform to the pattern of increased seasonal variability towards the north, this could be partly related to reduced investment in new shoots and/or slower shoot turnover in the colder north.

Information on eelgrass performance along the wide-ranging thermal latitude gradient may also provide hints on how eelgrass meadows may respond to future warming, using a space-for-time approach (Fukami \& Wardle 2005). For example, increases in production and depth extension of kelp southwards along Greenland's coast, where water temperatures are higher and the ice-free period longer, led to the prediction that kelp will gain a more prominent role in north Greenland in a warmer future (Krause-Jensen et al. 2012). Isotherms currently move northwards at a pace of $21.7 \mathrm{~km}$ per decade across the oceans (Burrows et al. 2011) and recently Poloczanska et al. (2013) demonstrated that phenology and abundance of marine taxa change along with ocean surface temperature changes. Hence, projected warming will potentially cause changes in the magnitude, timing and variability of eelgrass biomass and production, affecting the role of these meadows in coastal ecosystems. We hypothesize that the start of eelgrass growing season and timing of annual peak biomass will move forward with increasing summer temperatures. Accordingly, the longer ice-free periods in Arctic regions may extend the growing season of eelgrass in the present-day northern populations and stimulate a northward expansion of the species, as sexual reproduction currently seems limited by low water temperatures (Silberhorn et al. 1983, authors' unpubl. data). Southern populations might experience increased competition from tropical species, leading to a rangeshift in the species as a whole. 
Using previously published studies, we examined the magnitude and seasonality of eelgrass aboveground biomass and production across its distributional range and evaluated to what extent temperature and latitude (reflecting a combination of incoming irradiance and temperature) are important in accounting for potential differences between populations. Specifically, we wanted to characterize the following variables across the entire eelgrass distributional range: (1) size and timing of annual peak aboveground biomass, (2) start, end and length of the growing season, (3) mean annual aboveground biomass, annual biomass variability and above/belowground biomass ratio, (4) mean annual shoot density and annual variability in shoot density and (5) annual production and the turnover of biomass. Based on the results, we also aimed to evaluate potential future changes in biomass seasonality and production as a result of global warming.

\section{MATERIALS AND METHODS}

We extensively reviewed the previously published scientific literature to obtain studies that describe eelgrass aboveground biomass seasonality and production as well as the influence of temperature and latitude (Table 1, Fig. 1). This study included a total of 40 published studies of shallow eelgrass populations ( $\approx 0.5$ to $3 \mathrm{~m}$ depth) from across the northern hemisphere at latitudes ranging from $29.1^{\circ}$ to $66.2^{\circ} \mathrm{N}$, and summer (June to August) temperatures ranging from $10.5^{\circ}$ to $29.8^{\circ} \mathrm{C}$. Thus, our compilation encompassed populations from most of the eelgrass latitudinal range but excluded those at the northernmost edge (up to $69^{\circ} \mathrm{N}$, Olsen et al. 2013) due to the lack of seasonal studies.

\section{Eelgrass biomass and production}

During an annual cycle, eelgrass aboveground biomass development is more or less unimodal with a bell-shaped pattern (Olesen \& Sand-Jensen 1994b, Meling-Lopez \& Ibarra-Obando 1999), exhibiting a mid-season peak with low but consistent growth rates before and after this peak. The mid-season peak in biomass development representing the apparent growth period can be described as parabolic growth, and seasonal changes in eelgrass biomass can therefore be approximated by fitting quadratic equations to time-series measurements. Using this approach, the magnitude and timing of peak above- ground biomass was determined as the $\mathrm{y}$ and $\mathrm{x}$ coordinates of the parabola vertex, the start and end of the growing season as the 2 parabola roots, and the length of the growing season as the number of days between these roots.

We identified all spatially defined studies where changes in aboveground biomass seasonality followed a hump-shaped pattern with a single biomass peak, and included all studies with a reasonable quadratic fit $\left(\mathrm{R}^{2}>0.75\right.$, Table 1$)$. Most $(80 \%)$ eelgrass meadows included in the compiled studies fulfilled this demand, indicating that the criterion was reasonable. The studies that did not satisfy the hump-shaped pattern and the quadratic fit either failed to have a single welldefined biomass peak (e.g. Thom 1990), had more than one peak (e.g. Poumian-Tapia \& Ibarra-Obando 1999) or had very few data (Hedal 1992). Delineation of aboveground biomass as a quadratic function of date ensured that standardised objective measures were applied throughout the dataset, and in the analyses of peak biomass and timing of peak biomass and growth season, care was taken only to include the parabola-like summer peak in aboveground biomass development. In some cases data were only available from the growing season, whilst in others biomass measurements outside this period were omitted from the quadratic fitting analyses.

Mean annual aboveground biomass and mean annual shoot density was determined as the overall mean of all available measurements for each study where data on these parameters were presented, and annual variation in biomass and shoot density as the coefficient of variation (CV). Quantifying these measures did not rely on the abovementioned quadratic fit, and for this reason the sample sizes in these analyses included additional data sets not satisfying the criteria outlined above. The analysis of annual variation in aboveground biomass and shoot density (CV) was somewhat complicated by the habitatdependent life history strategy of eelgrass, as intertidal populations may sometimes demonstrate high seasonal variability and even develop an annual growth strategy, while subtidal populations are generally perennial (Phillips et al. 1983). Studies from intertidal populations (e.g. Van Lent \& Verschuure 1994) were consequently omitted from the analyses of annual variation. Belowground biomass was only reported in a subset of the included studies, but for all data sets with available data the above/belowground biomass ratio at time of maximum leaf biomass was calculated. All data on annual leaf biomass production were obtained with leaf marking techniques (viz. Short \& Duarte 2001). 
Table 1. References included in this study of eelgrass Zostera marina biomass seasonality and production. Some of these studies contained data from several spatially separate sites, and hence contributed more than one data point

\begin{tabular}{|c|c|c|c|c|c|}
\hline Reference & Country & $\begin{array}{l}\text { Sampling } \\
\text { years }\end{array}$ & $\begin{array}{l}\text { Latitude } \\
\left({ }^{\circ} \mathrm{N}\right)\end{array}$ & $\begin{array}{l}\text { Mean temp. } \\
\left({ }^{\circ} \mathrm{C} \text {, Jun-Aug }\right)\end{array}$ & $\begin{array}{l}\text { Seasonal } \\
\text { coverage }\end{array}$ \\
\hline Aioi (1980) & Japan & 1975-1976 & 35.1 & 24.3 & Mar-Dec \\
\hline Bach (1993) & Denmark & 1988 & 54.6 & 16.0 & May-Nov \\
\hline Beal et al. $(2004)^{\mathrm{a}}$ & Maine (USA) & 1995-1996 & 44.8 & 15.7 & Jan-Nov \\
\hline Cabello-Pasini et al. $(2003)^{a}$ & Mexico & $1999-2000$ & 30.3 & 23.3 & Jan-Dec \\
\hline Cebrián et al. (1997) & Spain & 1991-1993 & 42.3 & 21.8 & Jan-Dec \\
\hline Guidetti $(2000)^{\mathrm{a}}$ & Italy & 1997 & 45.7 & 21.9 & Feb-Dec \\
\hline Guidetti et al. (2002) & Italy & 1997 & 45.4 & 22.3 & Feb-Nov \\
\hline Hayashida $(2000)^{\mathrm{a}}$ & Japan & 1977 & 34.4 & 24.1 & May-Nov \\
\hline Heck \& Thoman (1984) & Virginia (USA) & $1978-1980$ & 37.4 & 24.4 & Mar-Nov \\
\hline Hedal $(1992)^{\mathrm{a}}$ & Denmark & 1991 & 55.4 & 16.2 & Apr-Sep \\
\hline Ibarra-Obando $(1989)^{\mathrm{a}}$ & Mexico & 1982 & 30.3 & 27.8 & Jun-Nov \\
\hline Jacobs (1979) & France & 1976 & 48.4 & 16.1 & Jan-Dec \\
\hline Kentula \& McIntire (1986) & Oregon (USA) & 1979-1981 & 45.2 & 13.9 & Feb-Sep \\
\hline Lalumiere et al. (1994) & Canada & 1986-1991 & 54.1 & 10.5 & Jun-Nov \\
\hline Lee et al. $(2004)^{\mathrm{b}}$ & Korea & $2002-2003$ & 35.1 & 24.2 & Jan-Dec \\
\hline Lee et al. (2005) & Korea & 2001-2003 & 34.5 & 24.0 & Jan-Dec \\
\hline Lee et al. (2006) & Korea & 2001-2002 & 34.7 & 23.9 & Jan-Dec \\
\hline Mcroy $(1974)^{a}$ & Alaska (USA) & Not given & 56.4 & 9.7 & Jun-Oct \\
\hline Meling-Lopez \& Ibarra-Obando (1999) & Mexico & $1997-1998$ & 29.1 & 29.7 & Jan-Dec \\
\hline Mizushima (1985) & Japan & 1980 & 43.6 & 15.2 & May-Dec \\
\hline Naumov (2007) & Russia & 1988-2002 & 66.2 & 12.3 & Apr-Oct \\
\hline Nelson \& Waaland (1997) & Washington (USA) & 1990-1992 & 48.3 & 16.2 & Jan-Dec \\
\hline Nienhuis \& De Bree (1980) & The Netherlands & $1974-1976$ & 51.4 & 16.5 & Jan-Dec \\
\hline Olesen \& Sand-Jensen (1994b) & Denmark & 1990-1991 & 56.4 & 15.2 & Mar-Oct \\
\hline Orth \& Heck (1980) & Virginia (USA) & $1976-1978$ & 37.3 & 24.6 & Jan-Dec \\
\hline Orth \& Moore (1986) & Virginia (USA) & $1978-1980$ & 37.2 & 24.6 & Jan-Dec \\
\hline Pedersen \& Borum (1993) & Denmark & 1988-1989 & 55.5 & 16.5 & Feb-Dec \\
\hline Penhale $(1977)^{\mathrm{a}}$ & North Carolina (USA) & 1974 & 34.4 & 25.6 & Jan-Dec \\
\hline Poumian-Tapia \& Ibarra-Obando (1999) ${ }^{\mathrm{a}}$ & Mexico & $1987-1988$ & 30.1 & 23.3 & Jan-Dec \\
\hline Robertson \& Mann (1984) & Canada & $1979-1980$ & 44.4 & 17.0 & Jan-Dec \\
\hline Roman \& Able (1988) & Massachusetts (USA) & 1986-1987 & 41.5 & 20.4 & Jan-Nov \\
\hline Sand-Jensen (1975) & Denmark & 1974 & 55.4 & 16.2 & Mar-Oct \\
\hline Sfriso \& Ghetti (1998) & Italy & 1994-1995 & 45.5 & 22.0 & Jan-Dec \\
\hline Taniguchi \& Yamada (1979) & Japan & $1975-1976$ & 37.3 & 23.1 & Jan-Dec \\
\hline Thom $(1990)^{\mathrm{a}}$ & Washington (USA) & $1986-1987$ & 49.0 & 15.0 & Jan-Aug \\
\hline Thorne-Miller et al. (1983) & Rhode Island (USA) & $1978-1980$ & 41.6 & 20.3 & Apr-Dec \\
\hline Van Lent \& Verschuure (1994) & The Netherlands & $1987-1989$ & 51.8 & 16.4 & Jan-Dec \\
\hline Watanabe et al. $(2005)^{\mathrm{a}}$ & Japan & $1999-2000$ & 43.0 & 15.9 & May-Dec \\
\hline Wetzel \& Penhale (1983) & Virginia (USA) & $1979-1980$ & 37.4 & 24.4 & Jan-Dec \\
\hline Wium-Andersen \& Borum (1984) ${ }^{\mathrm{a}}$ & Denmark & $1978-1979$ & 55.5 & 16.5 & Jan-Dec \\
\hline
\end{tabular}

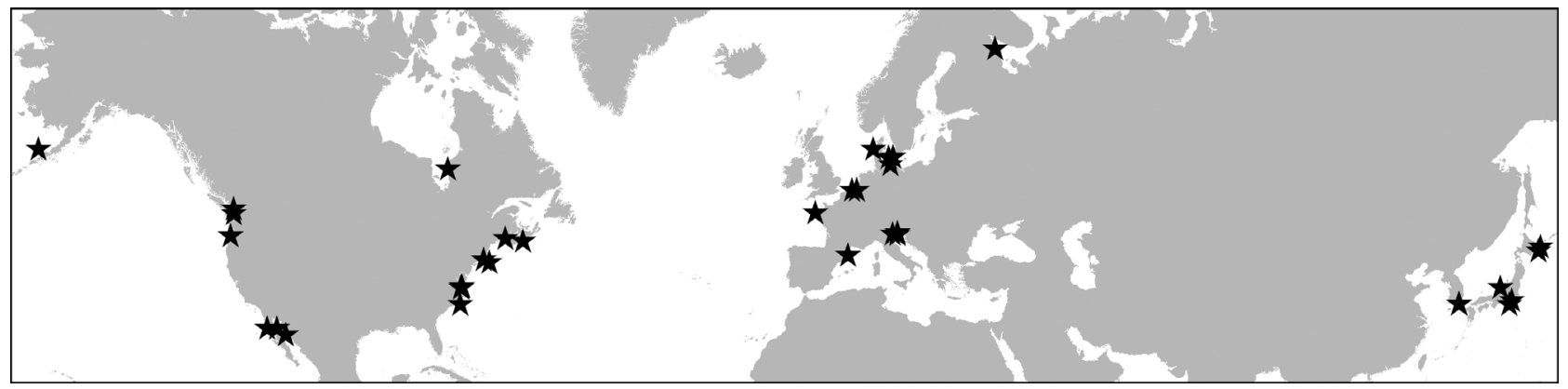

Fig. 1. Locations (stars) included in this study of eelgrass Zostera marina seasonality 
Some studies included only few measurements during the course of an entire year. The number of data points will undeniably affect several of the parameters measured in this study, and the varying number of measurements between studies can influence acceptability of the quadratic fit, annual variation (CV) and annual means. However, re-running the analyses with different subsets of studies $(>6$ and $>8$ data points $\mathrm{yr}^{-1}$ ) did not affect overall conclusions, but only resulted in declining power of the statistical analyses. As a consequence, we decided to include all available data. We found no significant trend in the amount of available data across latitude and temperature $\left(F_{1,33}<2.428, \mathrm{p}>0.129\right)$, and given the high number of data points in our analysis, we are confident that potential biases did not significantly influence the results.

\section{Temperature and latitude}

As a measure of temperature, we used long-term (1950 to 2000) site-specific summer means (June to August), independently derived from www.world clim.org (Hijmans et al. 2005), which provides free atmospheric climatic data for ecological modeling. Although local water temperatures were preferred in this study, the spatial detail necessary to incorporate local effects proved unavailable on the geographical scale covered here. Water temperature may depend strongly on local water currents and coastal topography, and may therefore differ from local air temperatures. In most circumstances, however, air temperature has been shown to be a good replacement of actual water temperature, because of the rapid heat exchange and resultant equilibrium between surface waters and the atmosphere (Cabello-Pasini et al. 2003, Lee et al. 2006). As a consequence, and to fully incorporate temperature differences on a fine spatial scale, we relied on air temperatures to model potential effects of temperature on eelgrass biomass and production. Latitudes were provided directly by the source literature, or in a few cases, inferred from detailed descriptions of the study sites. Latitude is directly linked to insolation, and therefore tightly coupled to both the amount of light and the amount of thermal heat reaching the Earth's surface. While availability of light is determined almost exclusively by latitudinal position of the Earth, substantial variation in temperature arise from several factors, including ocean currents, distribution of land masses and local hydrological conditions. If photo-period was the most important factor controlling seasonal aboveground biomass patterns of eelgrass meadows, latitude should therefore be a good predictor of observed patterns. In contrast, if temperature was the main driver behind these patterns, actual summer temperature of the study sites should be a better explanatory factor than latitude.

As would be expected, temperature and latitude were highly correlated (Pearson's $r=-0.87$ ), and separating the effects of individual predictors from multiple regression analyses was therefore troublesome, due to multicollinearity. As a consequence, the influence of covariates was examined by means of linear and quadratic regression analyses and subsequent model comparisons (using Akaike's Information Criterion [AIC], cf. Burnham \& Anderson 2002) between the fitted regressions of temperature and latitude on each dependent variable. The evidence ratio (how many times one model is a better fit to the data than another, sensu Motulsky \& Christopoulos 2004) between competing models served as a measure indicating how well temperature and latitude predicted the observed patterns. As a measure of how well the regression lines approximated the real data, the coefficient of determination $\left(\mathrm{R}^{2}\right)$ was calculated for all fits. For all regressions, normality of residuals was evaluated by normal quantile plots and Shapiro-Wilk test statistics.

\section{RESULTS}

Model comparisons between linear and quadratic fits did not support the inclusion of quadratic terms in any of the analyses describing effects of temperature and latitude on response variables ( $\triangle \mathrm{AIC}<2$ in all comparisons with quadratic fit as the best model). As a consequence, all reported regression analyses in this section are representative of linear relationships.

\section{Biomass seasonality}

The magnitude of the annual peak aboveground biomass varied greatly across the northern hemisphere (mean \pm SE: $246.2 \pm 22.6 \mathrm{~g} \mathrm{dw}$ [dry weight] $\mathrm{m}^{-2}$ ), with no clear effect of either summer temperature $\left(F_{1,45}=1.395, \mathrm{p}=0.244\right.$; Fig. $\left.2 \mathrm{a}\right)$ or latitude $\left(F_{1,45}=2.153, \mathrm{p}=0.149 ;\right.$ Fig. $\left.2 \mathrm{~b}\right)$. Timing of peak aboveground biomass $(194.1 \pm 4.9$ DOY [day of the year]) changed significantly across both temperature $\left(F_{1,45}=106.90, \mathrm{p}<0.001\right.$; Fig. $\left.2 \mathrm{c}\right)$ and latitude $\left(F_{1,45}=\right.$ 78.61, p < 0.001; Fig. 2d). Warmer areas and lower 


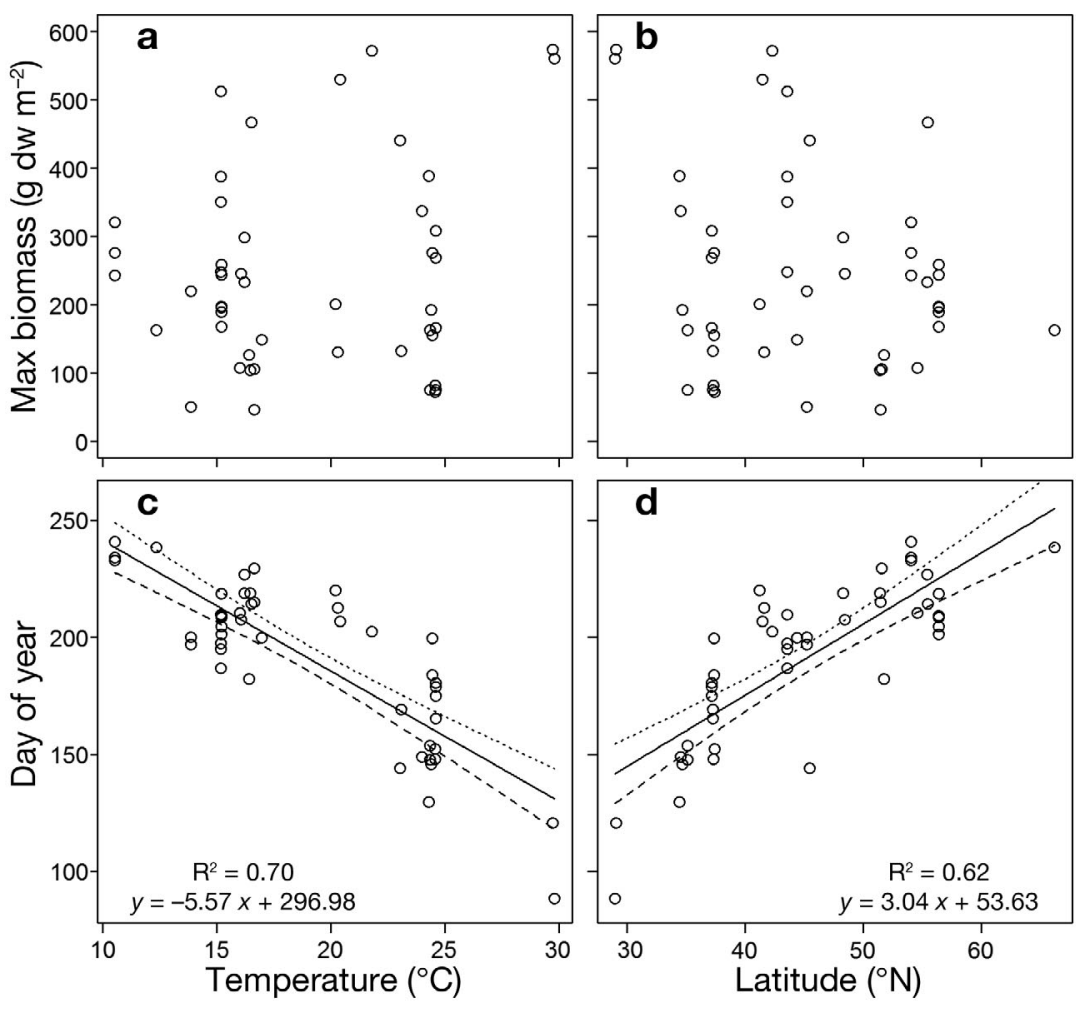

Fig. 2. (a,b) Peak aboveground biomass (dw: dry weight) and $(c, d)$ timing of peak biomass in eelgrass Zostera marina meadows as a function of $(\mathrm{a}, \mathrm{c})$ mean summer temperature (June to August) and (b,d) latitude. Solid lines indicate significant linear regressions; dashed lines are upper and lower $95 \% \mathrm{CI}$
Start of the growing season $(96.5 \pm$ 5.1 DOY) showed a significant regression with both temperature $\left(F_{1,45}=41.03, \mathrm{p}<0.001\right.$; Fig. 3a) and latitude $\left(F_{1,45}=28.16, \mathrm{p}<0.001\right.$; Fig. 3b), with an earlier start of the growing season associated with warmer areas and lower latitudes. Termination of the growing season $(291.7 \pm 6.2$ DOY $)$ showed a similar pattern, and ended earlier in areas with higher mean summer temperature $\left(F_{1,45}=70.68, \mathrm{p}<0.001\right.$; Fig. $\left.3 \mathrm{c}\right)$ and lower latitude $\left(F_{1,45}=66.81, \mathrm{p}<\right.$ 0.001; Fig. 3d). Overall the growth season started $4.64 \mathrm{~d}$ earlier and ended $6.36 \mathrm{~d}$ earlier per $1^{\circ} \mathrm{C}$ increase in temperature, and started $2.38 \mathrm{~d}$ earlier and ended $3.62 \mathrm{~d}$ earlier per $1^{\circ}$ latitude southward (Table 2). Although both start and end of the growth period was affected by temperature and latitude, the parallel advancement of these events resulted in a constant length of the growing season (192.6 \pm 4.9 DOY) across both gradients (temperature: $F_{1,45}=1.515, \mathrm{p}=0.225$; Fig. 3e; latitude: $F_{1,45}=2.918, \mathrm{p}=0.094$; Fig. 3f).

latitudes resulted in an earlier peak biomass, whereas cold areas at higher latitudes were associated with later peaks. Timing of the peak biomass moved forward by $5.5 \mathrm{~d}$ per $1^{\circ} \mathrm{C}$ increase in temperature and $3.0 \mathrm{~d}$ per $1^{\circ}$ latitude southward (Table 2 ).
Mean annual aboveground biomass (122.6 $\pm 8.4 \mathrm{~g}$ $\left.\mathrm{dw} \mathrm{m}^{-2}\right)$ tended to be larger in colder areas $\left(F_{1,62}=\right.$ 5.973, $\mathrm{p}=0.017$; Fig. 4a), but did not change significantly across latitudes $\left(F_{1,62}=2.273, \mathrm{p}=0.137\right.$ Fig. 4b). Annual variation in biomass (CV: $0.72 \pm$

Table 2. Model comparisons between the effects of mean summer temperature and latitude on each of the dependent variables measured. For each dependent variable, 'estimate' (with standard error [SE]) indicates the slope of the regression line $\left(\mathrm{R}^{2}\right)$ with mean summer temperature or latitude. The evidence ratios (ER) indicate how many times summer temperature is a better fit to the data than latitude. Temperatures were derived from www.worldclim.org (Hijmans et al. 2005). Significance levels: ${ }^{*} \mathrm{p}<0.05$, ${ }^{* *} \mathrm{p}<0.01,{ }^{* * *} \mathrm{p}<0.001$. DOY: day of the year

\begin{tabular}{|c|c|c|c|c|c|c|c|}
\hline \multirow[t]{2}{*}{ Dependent variable } & \multicolumn{3}{|c|}{ Temperature $\left({ }^{\circ} \mathrm{C}, \mathrm{M} 1\right)$} & \multicolumn{3}{|c|}{ Latitude $\left({ }^{\circ} \mathrm{N}, \mathrm{M} 2\right)$} & \multirow{2}{*}{$\begin{array}{c}\text { ER } \\
\text { (temperature: } \\
\text { latitude) }\end{array}$} \\
\hline & Estimate & $\mathrm{SE}$ & $\mathrm{R}^{2}$ & Estimate & $\mathrm{SE}$ & $\mathrm{R}^{2}$ & \\
\hline Size of peak biomass $\left(g \mathrm{dw} \mathrm{m}^{-2}\right)$ & 4.97 & 4.21 & 0.03 & -3.52 & 2.40 & 0.05 & 0.66 \\
\hline Timing of peak biomass (DOY) & $-5.57^{* * *}$ & 0.54 & 0.70 & $3.04^{* * *}$ & 0.34 & 0.63 & 124.00 \\
\hline Start of the growing season (DOY) & $-4.71^{* * *}$ & 0.74 & 0.48 & $2.43^{* * *}$ & 0.46 & 0.38 & 42.48 \\
\hline End of the growing season (DOY) & $-6.43^{* * *}$ & 0.76 & 0.61 & $3.65^{* * *}$ & 0.45 & 0.60 & 2.37 \\
\hline Length of the growing season (d) & -1.18 & 0.96 & 0.03 & 0.92 & 0.54 & 0.06 & 0.51 \\
\hline Mean annual biomass $\left(\mathrm{g} d w \mathrm{~m}^{-2}\right)$ & $-4.07^{*}$ & 1.67 & 0.09 & 1.38 & 0.91 & 0.04 & 6.58 \\
\hline Annual biomass variation (CV) & $0.023^{* * *}$ & 0.007 & 0.18 & -0.006 & 0.004 & 0.04 & 32.57 \\
\hline Above/belowground biomass ratio & $0.207^{* *}$ & 0.059 & 0.26 & $-0.100^{* *}$ & 0.031 & 0.23 & 2.34 \\
\hline Mean annual shoot density ( shoots $\mathrm{m}^{-2}$ ) & 9.38 & 19.79 & 0.01 & 5.63 & 10.74 & 0.01 & 0.97 \\
\hline Annual variation in shoot density (CV) & $0.014^{*}$ & 0.007 & 0.10 & -0.002 & 0.005 & 0.01 & 4.10 \\
\hline Aboveground production ( $\mathrm{g} \mathrm{dw} \mathrm{m}^{-2} \mathrm{yr}^{-1}$ ) & 1.392 & 31.30 & 0.00 & 14.61 & 15.48 & 0.04 & 0.62 \\
\hline
\end{tabular}



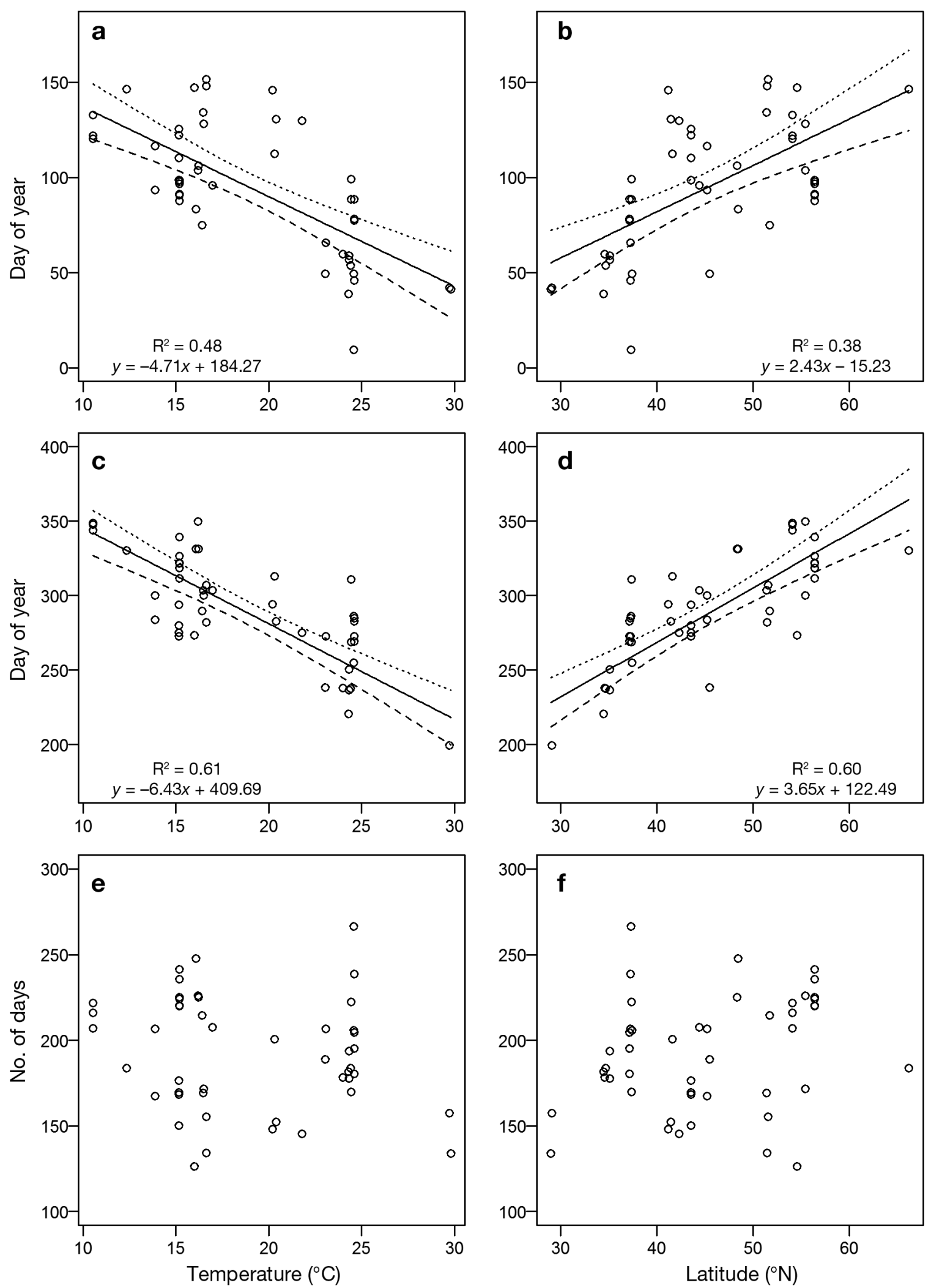

Fig. 3. $(a, b)$ Start of the growing season, $(c, d)$ end of the growing season and $(e, f)$ length of the growing season in eelgrass Zostera marina meadows as a function of $(\mathrm{a}, \mathrm{c}, \mathrm{e})$ mean summer temperature (June to August) and (b,d,f) latitude. Solid lines indicate significant linear regressions; dashed lines are upper and lower $95 \%$ CI 

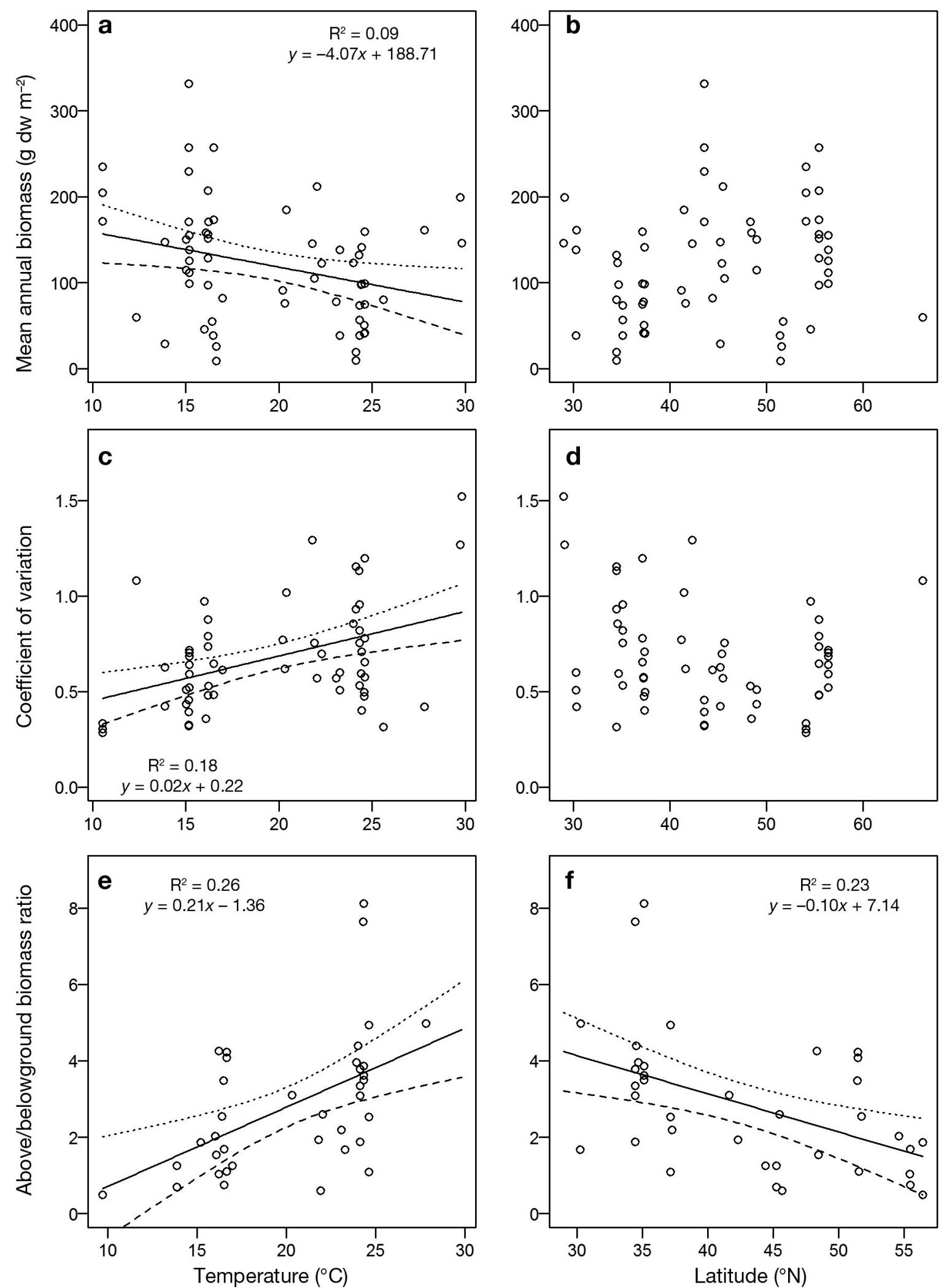

Fig. 4. (a,b) Mean annual biomass (dw: dry weight), (c,d) annual variation in biomass, and (e,f) above/belowground biomass ratio in eelgrass Zostera marina meadows as a function of $(\mathrm{a}, \mathrm{c}, \mathrm{e})$ mean summer temperature (June to August) and (b,d,f) latitude. Solid lines indicate significant linear regressions; dashed lines are upper and lower $95 \%$ CI 

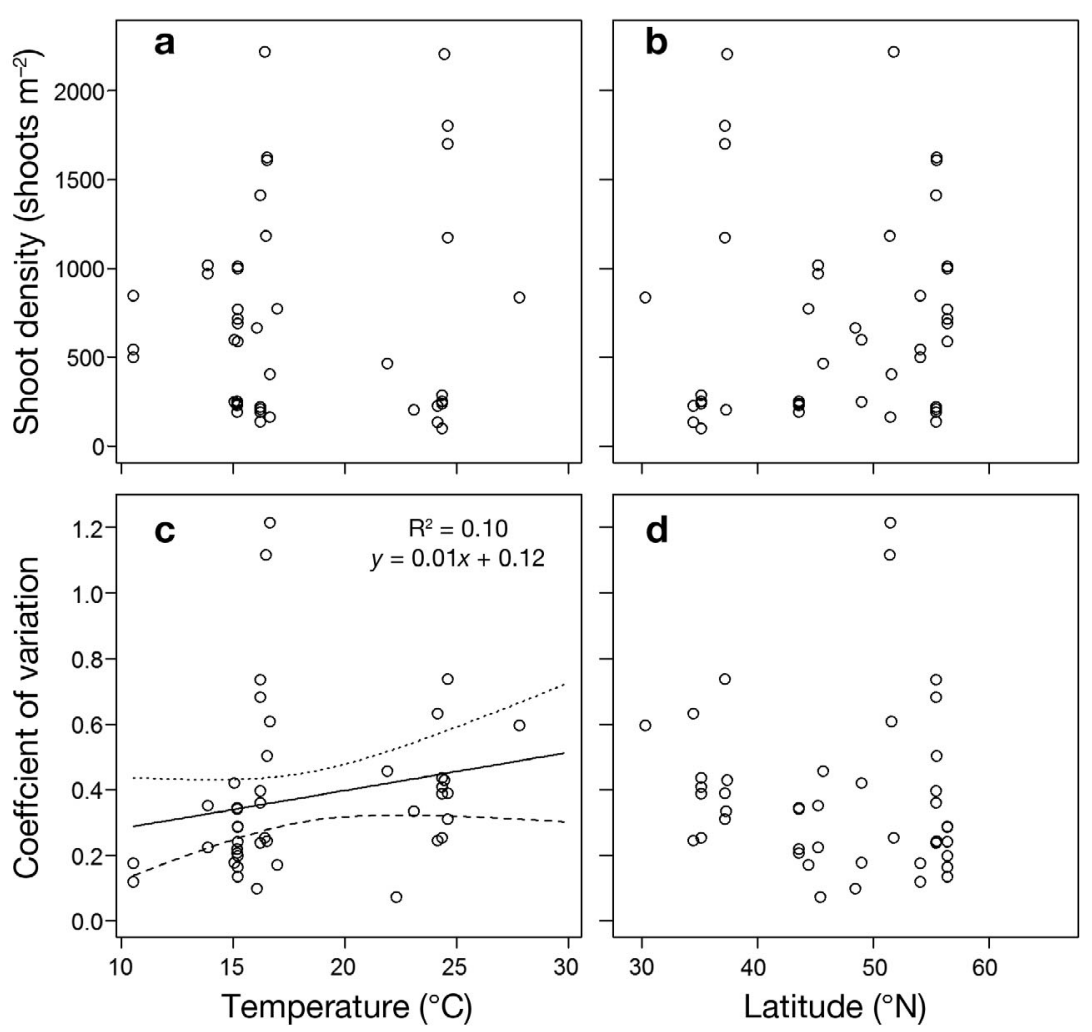

Fig. 5. (a,b) Mean annual shoot density and (c,d) annual variation in shoot density in eelgrass Zostera marina meadows as a function of $(\mathrm{a}, \mathrm{c})$ mean summer temperature (June to August) and (b,d) latitude. Solid lines indicate significant linear regressions, dashed lines are upper and lower $95 \%$ CI
$\left(F_{1,35}=10.350, \mathrm{p}=0.003 ;\right.$ Fig. $\left.4 \mathrm{f}\right)$, and these relationships were significant even with the exclusion of 2 possible outliers with very high ratios (Fig. 4e,f). The ratio increased by 0.207 per $1^{\circ} \mathrm{C}$ increase in temperature and by 0.100 per $1^{\circ}$ latitude southward (Table 2 ), and probably reflects a longer lifespan of belowground parts in the colder northern waters. Indeed, mean annual shoot density $(718.0 \pm 88.5$ shoots $\mathrm{m}^{-2}$ ) did not change across temperature $\left(F_{1,41}=0.225, \mathrm{p}=0.638\right.$; Fig. 5a) and latitude $\left(F_{1,41}=0.275, \mathrm{p}=\right.$ 0.603; Fig. 5b), but annual variation in shoot density (CV: $0.35 \pm 0.03)$ was larger in warmer areas $\left(F_{1,38}=4.295\right.$, $\mathrm{p}=0.045$; Fig. $5 \mathrm{c}$ ) - although it did not change significantly across the latitudinal gradient $\left(F_{1,38}=1.203, \mathrm{p}=\right.$ 0.280; Fig. 5d).

Available data on annual leaf production (mean \pm SE: $788.5 \pm 102.0 \mathrm{~g}$ $\mathrm{dw} \mathrm{m}^{-2} \mathrm{yr}^{-1}$ ) revealed no significant regression with either temperature $\left(F_{1,24}=0.002, \mathrm{p}=0.965\right.$; Fig. $\left.6 \mathrm{a}\right)$ or latitude $\left(F_{1,24}=0.891, \mathrm{p}=0.355\right.$; Fig. $\left.6 \mathrm{~b}\right)$. Biomass turnover (production/biomass ratio) ranged from 0.83 to 8.09 $0.04)$ was generally larger in warmer areas $\left(F_{1,59}=\right.$ $12.878, \mathrm{p}<0.001$; Fig. 4c), but did not exhibit a significant latitudinal gradient $\left(F_{1,59}=2.522, \mathrm{p}=0.118\right.$; Fig. $4 \mathrm{~d})$. Above/belowground biomass ratio $(2.8 \pm$ 0.29 ) at time of peak aboveground biomass was positively related to summer temperature $\left(F_{1,35}=12.490\right.$, $\mathrm{p}=0.001$; Fig. $4 \mathrm{e}$ ) and negatively related to latitude and was inversely related to temperature $\left(F_{1,23}=\right.$ 8.476, $\mathrm{p}=0.008$ ) but revealed no significant regression with latitude $\left(F_{1,23}=3.482, \mathrm{p}=0.075\right)$ (data not shown). Biomass turnover was calculated from a limited data set in which peak biomass tended to increase with temperature, as opposed to the larger data set where no significant regression between peak biomass and temperature was found. As biomass production was overall unaffected by temperature we therefore assumed that there was no overall indication of a temperature effect on biomass turnover.

\section{The effects of temperature and latitude}

Model comparisons between regression models with temperature or latitude as independent variables revealed that - for all significant linear regressions - temperature was the best predictor of the observed rela-
Fig. 6. Annual leaf production (dw: dry weight) of eelgrass Zostera marina meadows as a function of (a) mean summer temperature (June to August) and (b) latitude 
tionships (Table 2). In particular, timing of peak biomass, start of the growth season and annual biomass variation showed strong support for a dependence on temperature, with earlier growth season and larger biomass variability in warmer areas. Mean annual biomass and annual variation in shoot density were also considerably better explained by temperature than by latitude. The remaining growth parameters (size of peak biomass, end of the growing season, length of the growing season, above/belowground biomass ratio and leaf biomass production) all had evidence ratios $<3$, making it difficult to confidently determine any potential causal links (Kass \& Raftery 1995).

\section{DISCUSSION}

\section{Large-scale spatial patterns in eelgrass biomass and production}

The annual peak aboveground biomass of shallow water eelgrass populations was unaffected by largescale differences in seasonal climate across the range of latitudes $\left(29.1^{\circ}\right.$ to $\left.66.2^{\circ} \mathrm{N}\right)$ and summer air temperatures $\left(10.5\right.$ to $\left.29.8^{\circ} \mathrm{C}\right)$ studied here (Fig. 2). This confirms previous observations of eelgrass populations having the potential to develop high abundances even in Arctic regions, which are characterized by a short growing season with a low number of days available for biomass growth (McRoy 1970). The very large variability in peak aboveground biomass among populations in this study suggests that local factors can be more important than large scale factors in controlling biomass accumulation during the growth season. Physical exposure to waves and currents exerts major control on the biomass and distribution of shallow eelgrass populations (KrauseJensen et al. 2003) and is a likely key player in the regulation of peak biomass in shallow exposed areas. Other local factors such as unsuitable sediments (Koch 2001), eutrophication-enhanced shading due to light attenuation in the water column (KrauseJensen et al. 2003), shading by mats of filamentous macroalgae (Rasmussen et al. 2013) and top-down control (Baden et al. 2012) may also constrain biomass accumulation locally.

The annual mean aboveground biomass, by contrast, tended to be larger (Fig. 4a,b) and less variable (Fig. 4c,d) in colder areas, suggesting that coldwater populations are able to maintain high aboveground biomass during winter (McRoy 1969). This relationship contrasts previous findings where seagrasses in general showed less seasonality at lower latitudes, attributable to a longer growing season and a more constant light climate (Duarte 1989). Low seasonal variability in cold-water populations is also suggested by recent findings in Greenland, where eelgrass populations develop a high summer biomass, although annual leaf formation rates are substantially lower than further south, and populations are probably unable to support large changes in size during seasonal biomass development (authors' unpubl. data). The more stable population dynamics of cold-water eelgrass populations might be related to reduced respiration and decomposition rates at lower temperatures (Brown et al. 2004), enabling the maintenance of a high biomass during winter. High seasonality of eelgrass biomass towards warmer areas, on the other hand, may occur in populations that experience severe die-back at high temperatures during late summer (Orth \& Moore 1986) and near the southern distribution limit of eelgrass, where populations are often annual as they survive the warm summer as seeds (Phillips et al. 1983, Meling-Lopez \& Ibarra-Obando 1999). The lower seasonal fluctuations in eelgrass aboveground biomass of cold-water populations might be partly explained by the finding that shoot density fluctuations are lower here too (Fig. 5c). Populations in colder areas may therefore extend shoot life span, requiring less investment in energyexpensive production of new shoots through clonal growth at the start of the growing season; and the gradual decrease in biomass fluctuations along the warm-cold gradient may be a consequence of reduced shoot turnover and increased shoot life span northwards. However, wide ranges of seasonal biomass variability occurred over the entire range of latitudes included, which emphasizes that effects of the annual climatic cycle can be obscured by other drivers (e.g. disturbance) of population variability.

Results from the analysis of above/belowground biomass ratio indicated that eelgrass meadows growing under warm conditions at low latitudes invested comparatively less energy in roots and rhizomes relative to leaves (Fig 4e,f), a strategy that matches well with annual growth patterns and complete seasonal loss of belowground parts (Meling-Lopez \& IbarraObando 1999).

Annual leaf production of eelgrass ranged 12-fold among populations, with no clear trend across either latitude or temperature gradients. However, data were only available from a rather narrow range of latitudes $\left(35^{\circ}\right.$ to $\left.56^{\circ} \mathrm{N}\right)$ and summer temperatures (14 to $24^{\circ} \mathrm{C}$ ). The lack of a clear trend in aboveground 
biomass production might relate to the somewhat offsetting effects of slow annual leaf formation rates in northern populations (authors' unpubl. data) and a shorter period of aboveground biomass development in the south (Meling-Lopez \& Ibarra-Obando 1999, Jarvis et al. 2012).

Parameters reflecting the timing of eelgrass aboveground biomass development (timing of peak biomass, start and end of the growing season) showed clear large scale patterns closely coupled to gradients in temperature and latitude (Figs. 2c,d \& 3a-d). All 3 parameters advanced considerably at higher temperatures and lower latitudes, resulting in a forward shifting of the entire growing season when moving from cold, high-latitude areas towards warmer low-latitude regions. As a consequence, the length of the growing season did not change significantly along any of the 2 gradients (Fig. 3e,f). The changing seasonality of eelgrass biomass seemed to be principally driven by differences in temperature, as variation in all significantly changing parameters relating to seasonal dynamics were better explained by mean summer temperature than by latitude (Table 2). The mid-summer drop in biomass found near the southern limit of eelgrass distribution may be related to growth inhibition as well as increased leaf loss and shoot mortality at high temperatures (Phillips et al. 1983, Lee et al. 2005, Jarvis et al. 2012). Negative impacts of high water temperature has been attributed to (1) increased respiration rate relative to photosynthesis, generating carbon imbalance in the plants, and (2) heat stress, which may also result in damaged membranes and enzymes leading to impairment of the photosynthetic system (Marsh et al. 1986, Taiz \& Zeiger 2010, Franssen et al. 2011). Increased shoot mortality during periods in late summers with unusually high temperature can also be related to oxygen stress leading to meristematic degradation. This may result from an indirect effect of low water column oxygen due to high microbial activity in the sediments, or by the direct effect of high respiratory oxygen demand in the plants which can lead to anoxic meristematic tissue even at relatively high water column oxygen concentrations (Raun \& Borum 2013). A comprehensive evaluation on how temperature affects several physiological and fitness-related variables (photosynthesis, respiration, leaf elongation rate, shoot size, survival, etc.) is given by Nejrup \& Pedersen (2008). Consequently, high summer temperatures may also play a role in explaining why the growing season of eelgrass tends to move forward rather than become extended in warm areas.

\section{Potential responses of eelgrass growth dynamics to warming}

Findings from this study may provide hints that help predict changes in seasonal dynamics of eelgrass biomass in response to future global warming. Temperature was identified in our study as the most important driver behind the variation in all significantly changing parameters across the northern hemisphere (Table 2), allowing a space-for-time approach to cautiously predict future changes (Fukami $\&$ Wardle 2005). Thus, the slope estimates of the linear regression analyses in Table 2 might serve as an indication of how single parameters respond to increasing temperatures. The most striking realisation from this approach might be that eelgrass biomass dynamics can be expected to advance 5 or $6 \mathrm{~d}$ for each $1^{\circ} \mathrm{C}$ warming. Timing of peak biomass, start of the growing season and end of the growing season all showed clear progressive trends as a result of higher mean summer temperatures, and a global temperature rise of $3.4^{\circ} \mathrm{C}$ (equivalent to the A2 scenario in IPCC 2007) would result in a $\sim 19 \mathrm{~d}$ earlier peak in eelgrass biomass by 2090 to 2099 .

Over the past $50 \mathrm{yr}$, the rate of warming at sea and on land between 30 and $60^{\circ} \mathrm{N}$ has averaged 0.13 and $0.30^{\circ} \mathrm{C}$ per decade, with some coastal areas warming at $\sim 0.5^{\circ} \mathrm{C}$ per decade, respectively (Burrows et al. 2011). This implies that the start of the growing season and peak aboveground biomass of eelgrass meadows (Table 2) might have advanced by 1 to $3 \mathrm{~d}$ per decade during this period, which is at the slowest range of that reported for other marine organisms (average $=4.4 \mathrm{~d}$ per decade; Poloczanska et al. 2013).

Evidence is quickly piling up that global warming is uneven across the globe (Burrows et al. 2011) and it will affect Arctic areas to a greater extent than southern latitudes (Høye et al. 2007, Clausen \& Clausen 2013). Thus, the changing seasonality might be amplified in cold water populations compared to those in temperate areas. If these predictions hold, the consequences of changing biomass seasonality may extend beyond eelgrass ecology. Eelgrass is a keystone species of many coastal habitats, and entire communities of birds, fish, arthropods and algae, as well as numerous epiphytic and epibenthic organisms, might face substantial changes in the structure and seasonality of coastal habitats (Franco et al. 2006, Waycott et al. 2009). The role of eelgrass in nutrient cycling, wave dampening, sediment suspension and carbon sequestration may likewise be altered (Widdows et al. 2008, van Katwijk et al. 2010). Our find- 
ings indicate that while eelgrass seasonality might respond strongly to a warming world, maximum biomass, annual production and annual shoot density are likely to be largely unaffected, or at least mainly influenced by other factors. As a consequence, the ecological effects related to the structural composition of eelgrass habitats may be relatively minor, whereas effects related to temporal dynamics may be much more pronounced. Rather than a steady rise in temperature, extreme events are expected to become increasingly important as a result of global warming (IPCC 2007), and the potential temperature stress associated with these events may be especially significant to eelgrass biomass dynamics.

To herbivorous waterbirds foraging directly on eelgrass leaves in temperate areas during early autumn, the forward shift in available aboveground biomass might lead to extensive declines in suitable autumn foraging habitats. This expected loss of preferred food sources could, in turn, result in lower winter survival (Clausen et al. 2012). So far, most autumn phenologies of herbivorous waterbirds have been unchanged or even delayed (Lehikoinen \& Jaatinen 2012), and ultimately this development may result in a phenological mismatch between food availability and waterbird arrival in their autumn staging areas. The mechanisms behind the apparently restricted window of substantial aboveground eelgrass growth are not completely understood, but seem to be related to rapidly declining photosynthesis/respiration ratios at high temperatures (Marsh et al. 1986, Lee et al. 2005). However, changing light attenuation and nutrient availability may also affect the length of the period with suitable environmental conditions for continued growth (Nelson \& Waaland 1997, Kaldy \& Lee 2007).

In addition to a general forward shifting of the growth season in a warmer future, it is also highly likely that the distribution of eelgrass will move northward, as has been predicted for temperate macroalgae (Muller et al. 2009, Krause-Jensen et al. 2012). Whereas biomass development of populations at the northern distributional edge does not seem limited, low temperatures seem to limit reproduction by seeds and reduce the possibility for expansion and northward spread of eelgrass meadows (authors' unpubl. data.). A warmer future is therefore likely to stimulate a northward expansion of the leading edge of distribution. The southern distributional limit is also likely to move northward in a warmer future because high temperatures exert substantial pressure on those populations (Jarvis et al. 2012). It should be noted that eelgrass populations most likely differ considerably in local adaptation and plasticity to temperature tolerance. For example, some mid-latitude populations may also be threatened by increasing temperatures, as these could suffer comparatively more from temperature stress than populations more adapted to coping with temperature extremes. Hence, Franssen et al. (2011) found that in terms of gene expression patterns, recovery from thermal stress $\left(25\right.$ to $\left.27^{\circ} \mathrm{C}\right)$ was delayed in plants from mid-latitude populations compared to southern populations.

Eelgrass is known to show great plasticity in both growth strategy and life-history traits across its distributional range (Phillips et al. 1983, Jarvis et al. 2012), and acclimation to local environments is a characteristic of many eelgrass meadows (Olesen \& SandJensen 1993, Kaldy \& Lee 2007). The wide range of factors regulating eelgrass growth substantially complicates identification of overall patterns, and fully clarifying how large-scale differences in temperature and light affect eelgrass seasonality relies on the ability to control local regulating factors. These factors include local differences in habitat conditions which also affect eelgrass, e.g. light attenuation, exposure, sediment conditions, nutrient levels, and competition, which were impossible to quantify in this study. Likewise, obtaining local water temperatures instead of local air temperatures could potentially improve the explanatory power of this environmental driver. However, including these factors relies on thorough knowledge of individual sites, and is not feasible given the geographical scope of this study. In summary, despite the great plasticity of eelgrass growth patterns and the many factors that control eelgrass dynamics, our results suggest a strong effect of temperature on biomass seasonality. Deciphering the exact physiological limitations behind these consistent temporal patterns might further advance our understanding of how climatic change can alter the key structural and trophic role of eelgrass in coastal ecosystems.

Acknowledgements. This work was supported by the European Union's Seventh Framework Program, grant agreement no. 226248 - Arctic Tipping Points (ATP) and the Greenland Climate Research Centre. We are very thankful to 3 anonymous reviewers, Carlos Duarte, and Morten Foldager Pedersen for constructive comments to an earlier draft.

\section{LITERATURE CITED}

Aioi K (1980) Seasonal change in the standing crop of eelgrass (Zostera marina L) in Odawa Bay, central Japan. Aquat Bot 8:343-354 
Bach HK (1993) A dynamic model describing the seasonal variations in growth and the distribution of eelgrass (Zostera marina L). 1. Model theory. Ecol Model 65: 31-50

Baden S, Emanuelsson A, Pihl L, Svensson CJ, Aberg P (2012) Shift in seagrass food web structure over decades is linked to overfishing. Mar Ecol Prog Ser 451:61-73

$>$ Beal BF, Vadas RL, Wright WA, Nickl S (2004) Annual aboveground biomass and productivity estimates for intertidal eelgrass (Zostera marina L.) in Cobscook Bay, Maine. Northeast Nat 11:197-224

Brown JH, Gillooly JF, Allen AP, Savage VM, West GB (2004) Toward a metabolic theory of ecology. Ecology 85: 1771-1789

Burnham KP, Anderson DR (2002) Model selection and multi-model inference: a practical information-theoretic approach. Springer, New York

Burrows MT, Schoeman DS, Buckley LB, Moore P and others (2011) The pace of shifting climate in marine and terrestrial ecosystems. Science 334:652-655

> Cabello-Pasini A, Muniz-Salazar R, Ward DH (2003) Annual variations of biomass and photosynthesis in Zostera marina at its southern end of distribution in the North Pacific. Aquat Bot 76:31-47

> Cebrián J, Duarte CM, Marba N, Enriquez S (1997) Magnitude and fate of the production of four co-occurring western Mediterranean seagrass species. Mar Ecol Prog Ser 155:29-44

> Clausen KK, Clausen P (2013) Earlier Arctic springs cause phenological mismatch in long-distance migrants. Oecologia 173:1101-1112

> Clausen KK, Clausen P, Faelled CC, Mouritsen KN (2012) Energetic consequences of a major change in habitat use: endangered Brent geese Branta bernicla hrota losing their main food resource. Ibis 154:803-814

> Duarte CM (1989) Temporal biomass variability and production/biomass relationships of seagrass communities. Mar Ecol Prog Ser 51:269-276

Duarte CM (1991) Allometric scaling of seagrass form and productivity. Mar Ecol Prog Ser 77:289-300

> Fonseca G, Hutchings P, Gallucci F (2011) Meiobenthic communities of seagrass beds (Zostera capricorni) and unvegetated sediments along the coast of New South Wales, Australia. Estuar Coast Shelf Sci 91:69-77

Franco A, Franzoi P, Malavasi S, Riccato F, Torricelli P (2006) Fish assemblages in different shallow water habitats of the Venice lagoon. Hydrobiologia 555:159-174

Franssen SU, Gu J, Bergmann N, Winters G and others (2011) Transcriptomic resilience to global warming in the seagrass Zostera marina, a marine foundation species. Proc Natl Acad Sci USA 108:19276-19281

Fukami T, Wardle DA (2005) Long-term ecological dynamics: reciprocal insights from natural and anthropogenic gradients. Proc R Soc Lond B Biol Sci 272:2105-2115

Green EP, Short FT (2003) World atlas of seagrasses. University of California Press, Berkeley, CA

Guidetti P (2000) Temporal dynamics of Zostera marina L. off the Lagoon of Grado (northern Adriatic Sea, Italy). Bot Mar 43:541-546

> Guidetti P, Lorenti M, Buia MC, Mazzella L (2002) Temporal dynamics and biomass partitioning in three Adriatic seagrass species: Posidonia oceanica, Cymodocea nodosa, Zostera marina. Mar Ecol 23:51-67

Hayashida F (2000) Vertical distribution and seasonal varia- tion of eelgrass beds in Iwachi Bay, Izu Peninsula, Japan. Hydrobiologia 428:179-185

> Heck KL, Thoman TA (1984) The nursery role of seagrass meadows in the upper and lower reaches of the Chesapeake Bay. Estuaries 7:70-92

Hedal S (1992) Bundvegetation i de indre dele af Roskilde Fjord og Isefjord. Miljøkontoret, Roskilde Amt

Hijmans RJ, Cameron SE, Parra JL, Jones PG, Jarvis A (2005) Very high resolution interpolated climate surfaces for global land areas. Int J Climatol 25:1965-1978

> Høye TT, Post E, Meltofte H, Schmidt NM, Forchhammer MC (2007) Rapid advancement of spring in the High Arctic. Curr Biol 17:R449-R451

Ibarra-Obando SE (1989) Las praderas de pastos marinos del Pacifico Mexicano con enfasis en Zostera marina L. In: Rosa-Vélez JDL, González-Farias F (eds) Temas de oceanografia biológica en Mexico. Universidad Autonoma de Baja California, Ensenada, p 1-20

IPCC (2007) Fourth Assessment Report (AR4). Cambridge University Press, New York

Jacobs RPWM (1979) Distribution and aspects of the production and biomass of eelgrass, Zostera marina L, at Roscoff, France. Aquat Bot 7:151-172

> Jarvis JC, Moore KA, Kenworthy WJ (2012) Characterization and ecological implication of eelgrass life history strategies near the species' southern limit in the western North Atlantic. Mar Ecol Prog Ser 444:43-56

Kaldy JE, Lee KS (2007) Factors controlling Zostera marina L. growth in the eastern and western Pacific Ocean: comparisons between Korea and Oregon, USA. Aquat Bot 87 : 116-126

Kass RE, Raftery AE (1995) Bayes factors. J Am Stat Assoc 90:773-795

> Kentula ME, McIntire CD (1986) The autecology and production dynamics of eelgrass (Zostera marina L) in Netarts Bay, Oregon. Estuaries 9:188-199

> Koch EM (2001) Beyond light: physical, geological, and geochemical parameters as possible submersed aquatic vegetation habitat requirements. Estuaries 24:1-17

> Krause-Jensen D, Pedersen MF, Jensen C (2003) Regulation of eelgrass (Zostera marina) cover along depth gradients in Danish coastal waters. Estuaries 26:866-877

> Krause-Jensen D, Markager S, Dalsgaard T (2012) Benthic and pelagic primary production in different nutrient regimes. Estuar Coast 35:527-545

> Lalumiere R, Messier D, Fournier JJ, Mcroy CP (1994) Eelgrass meadows in a low arctic environment, the northeast coast of James Bay, Quebec. Aquat Bot 47:303-315

> Lee KS, Park JI, Chung IK, Kang DW, Huh SH (2004) Production ecology of the seagrass Zostera marina in Jindong Bay, Korea. Algae 19:39-47

Lee KS, Park SR, Kim JB (2005) Production dynamics of the eelgrass, Zostera marina in two bay systems on the south coast of the Korean peninsula. Mar Biol 147:1091-1108

Lee SY, Kim JB, Lee SM (2006) Temporal dynamics of subtidal Zostera marina and intertidal Zostera japonica on the southern coast of Korea. Mar Ecol 27:133-144

Lehikoinen A, Jaatinen K (2012) Delayed autumn migration in northern European waterfowl. J Ornithol 153:563-570

> Marsh JA, Dennison WC, Alberte RS (1986) Effects of temperature on photosynthesis and respiration in eelgrass (Zostera marina L.). J Exp Mar Biol Ecol 101:257-267

McRoy CP (1969) Eelgrass under Arctic winter ice. Nature 224:818-819 
McRoy CP (1970) Standing stocks and other features of eelgrass (Zostera marina) populations on the coast of Alaska. J Fish Res Board Can 27:1811-1821

McRoy CP (1974) Seagrass productivity - carbon uptake experiments in eelgrass, Zostera marina. Aquaculture 4: 131-137

Meling-Lopez AE, Ibarra-Obando SE (1999) Annual life cycles of two Zostera marina L. populations in the Gulf of California: contrasts in seasonality and reproductive effort. Aquat Bot 65:59-69

Mizushima T (1985) Seasonal changes in standing crop and production of eelgrass (Zostera marina Linné) in Notsuke Bay, eastern Hokkaido. Hokkaido Kushiro Fish Exp Stat 27:111-118

Motulsky H, Christopoulos A (2004) Fitting models to biological data using linear and nonlinear regression: a practical guide to curve fitting. Oxford University Press, New York, NY

> Muller R, Laepple T, Bartsch I, Wiencke C (2009) Impact of oceanic warming on the distribution of seaweeds in polar and cold-temperate waters. Bot Mar 52:617-638

Naumov AD (2007) Long-term investigations of littoral benthos of the White Sea in the Chupa Guba (Kandalaksha Bay): seasonal and long-term dynamics of the biomass of the eelgrass Zostera marina. Complex investigations of processes, characteristics and resources of Russian seas of the north European basin, Vol 2. Kola Science Center, Apatity, p 493-502 (in Russian)

Nejrup LB, Pedersen MF (2008) Effects of salinity and water temperature on the ecological performance of Zostera marina. Aquat Bot 88:239-246

> Nelson TA, Waaland JR (1997) Seasonality of eelgrass, epiphyte, and grazer biomass and productivity in subtidal eelgrass meadows subjected to moderate tidal amplitude. Aquat Bot 56:51-74

Nienhuis PH, De Bree BHH (1980) Production and growth dynamics of eelgrass (Zostera marina) in brackish Lake Grevelingen (The Netherlands). Neth J Sea Res 14: 102-118

> Nienhuis PH, Groenendijk AM (1986) Consumption of eelgrass (Zostera marina) by birds and invertebrates - an annual budget. Mar Ecol Prog Ser 29:29-35

Olesen B, Sand-Jensen K (1993) Seasonal acclimatization of eelgrass Zostera marina growth to light. Mar Ecol Prog Ser 94:91-99

Olesen B, Sand-Jensen K (1994a) Biomass-density patterns in the temperate seagrass Zostera marina. Mar Ecol Prog Ser 109:283-291

> Olesen B, Sand-Jensen K (1994b) Demography of shallow eelgrass (Zostera marina) populations - shoot dynamics and biomass development. J Ecol 82:379-390

> Olsen JL, Coyer JA, Stam WT, Moy FE, Christie H, Jorgensen NM (2013) Eelgrass Zostera marina populations in northern Norwegian fjords are genetically isolated and diverse. Mar Ecol Prog Ser 486:121-132

> Orth RJ, Heck KL (1980) Structural components of eelgrass (Zostera marina) meadows in the lower Chesapeake Bay -Fishes. Estuaries 3:278-288

Orth RJ, Moore KA (1986) Seasonal and year to year variations in the growth of Zostera marina L (eelgrass) in the lower Chesapeake Bay. Aquat Bot 24:335-341

Pedersen MF, Borum J (1993) An annual nitrogen budget for a seagrass Zostera marina population. Mar Ecol Prog Ser 101:169-177
Penhale PA (1977) Macrophyte-epiphyte biomass and productivity in an eelgrass (Zostera marina L) community. J Exp Mar Biol Ecol 26:211-224

Phillips RC, Grant WS, Mcroy CP (1983) Reproductive strategies of eelgrass (Zostera marina L). Aquat Bot 16: $1-20$

Poloczanska ES, Brown CJ, Sydeman WJ, Kiessling W and others (2013) Global imprint of climate change on marine life. Nat Clim Change 3:919-925

> Poumian-Tapia M, Ibarra-Obando SE (1999) Demography and biomass of the seagrass Zostera marina in a Mexican coastal lagoon. Estuaries 22:837-847

> Rasmussen JR, Pedersen MF, Olesen B, Nielsen SL, Pedersen TM (2013) Temporal and spatial dynamics of ephemeral drift-algae in eelgrass, Zostera marina, beds. Estuar Coast Shelf Sci 119:167-175

Raun AL, Borum J (2013) Combined impact of water column oxygen and temperature on internal oxygen status and growth of Zostera marina seedlings and adult shoots. J Exp Mar Biol Ecol 441:16-22

> Robertson AI, Mann KH (1984) Disturbance by ice and lifehistory adaptations of the seagrass Zostera marina. Mar Biol 80:131-141

Roman CT, Able KW (1988) Production ecology of eelgrass (Zostera marina L) in a Cape Cod salt-marsh estuarine system, Massachusetts. Aquat Bot 32:353-363

> Sand-Jensen K (1975) Biomass, net production and growth dynamics in an eelgrass (Zostera marina L.) population in Vellerup Vig, Denmark. Ophelia 14:185-201

> Sfriso A, Ghetti PF (1998) Seasonal variation in biomass, morphometric parameters and production of seagrasses in the lagoon of Venice. Aquat Bot 61:207-223

Short FT, Duarte CM (2001) Methods for the measurement of seagrass growth and production. In: Short FT, Coles RG (eds) Global seagrass research methods. Elsevier, Amsterdam, p 155-182

Silberhorn GM, Orth RJ, Moore KA (1983) Anthesis and seed production in Zostera marina L (eelgrass) from the Chesapeake Bay. Aquat Bot 15:133-144

Taiz L, Zeiger E (2010) Plant physiology. Sinauer Associates, Sunderland, MA

Taniguchi K, Yamada Y (1979) Vertical distribution and natural life history of Zostera marina Linné and some other species of sea-grass in Iida Bay of the Noto Peninsula on the Honshu, Japan Sea coast. Bull Japan Sea Reg Fish Res Lab 30:111-122

Thom RM (1990) Spatial and temporal patterns in plant standing stock and primary production in a temperate seagrass system. Bot Mar 33:497-510

Thorne-Miller B, Harlin MM, Thursby GB, Brady-Campbell MM, Dworetzky BA (1983) Variations in the distribution and biomass of submerged macrophytes in five coastal lagoons in Rhode Island, USA. Bot Mar 26:231-242

> van Katwijk MM, Bos AR, Hermus DCR, Suykerbuyk W (2010) Sediment modification by seagrass beds: muddification and sandification induced by plant cover and environmental conditions. Estuar Coast Shelf Sci 89: $175-181$

> Van Lent F, Verschuure JM (1994) Intraspecific variability of Zostera marina L (eelgrass) in the estuaries and lagoons of the southwestern Netherlands. II. Relation with environmental factors. Aquat Bot 48:59-75

Watanabe M, Nakaoka M, Mukai H (2005) Seasonal variation in vegetative growth and production of the endemic 
Japanese seagrass Zostera asiatica: a comparison with sympatric Zostera marina. Bot Mar 48:266-273

- Waycott M, Duarte CM, Carruthers TJB, Orth RJ and others (2009) Accelerating loss of seagrasses across the globe threatens coastal ecosystems. Proc Natl Acad Sci USA 106:12377-12381

Wetzel RL, Penhale PA (1983) Production ecology of seagrass communities in the lower Chesapeake Bay. Mar Technol Soc J 17:22-31

Editorial responsibility: Morten Pedersen,

Roskilde, Denmark
Widdows J, Pope ND, Brinsley MD, Asmus H, Asmus RM (2008) Effects of seagrass beds (Zostera noltii and $Z$. marina) on near-bed hydrodynamics and sediment resuspension. Mar Ecol Prog Ser 358:125-136

Wium-Andersen S, Borum J (1984) Biomass variation and autotrophic production of an epiphyte-macrophyte community in a coastal Danish area. 1. Eelgrass (Zostera marina L) biomass and net production. Ophelia 23:33-46

Submitted: October 24, 2013; Accepted: March 3, 2014 Proofs received from author(s): June 2, 2014 